\title{
A Study on the Laser-Assisted Machining of Carbon Fiber Reinforced Silicon Carbide
}

\author{
Khulan Erdenechimeg ${ }^{1}$, Ho-In Jeong ${ }^{1}$ and Choon-Man Lee ${ }^{2, *(\mathbb{D}}$ \\ 1 Mechanical Design and Manufacturing, School of Mechatronics Engineering, Changwon National \\ University, 20, Changwondaehak-ro, Uichang-gu, Changwon-si, Gyeongsangnam-do 51140, Korea \\ 2 Departement of Mechanical Engineering, College of Mechatronics, Changwon National University, 20, \\ Changwondaehak-ro, Uichang-gu, Changwon-si, Gyeongsangnam-do 51140, Korea \\ * Correspondence: cmlee@changwon.ac.kr; Tel.: +82-55-213-3622
}

Received: 31 May 2019; Accepted: 26 June 2019; Published: 27 June 2019

check for updates

\begin{abstract}
In recent years, as replacements for traditional manufacturing materials, monolithic ceramics and carbon fiber reinforced silicon carbide $(\mathrm{C} / \mathrm{SiC})$ ceramic matrix composites have seen significantly increased usage due to their superior characteristics of relatively low density, lightweight, and good high temperature mechanical properties. Demand for difficult-to-cut materials is increasing in a variety of area such as the automotive and aerospace industries, but these materials are inherently difficult to process because of their high hardness and brittleness. When difficult-to-cut materials are processed by conventional machining, tool life and quality are reduced due to the high cutting force and temperatures. Laser-assisted machining (LAM) is a method of cutting a workpiece by preheating with a laser heat source and lowering the strength of the material. LAM has been studied by many researchers, but studies on LAM of carbon-ceramic composites have been carried out by only a few researchers. This paper focuses on deducing the optimal machining parameters in the LAM of C/SiC. In this study, the Taguchi method is used to obtain the major parameters for the analysis of cutting force and surface roughness under various machining conditions. Before machining experiments, finite element analysis is performed to determine the effective depth of the cut. The cutting parameters for the LAM operation are the depth of cut, preheating temperature, feed rate, and spindle speed. The signal to noise $(\mathrm{S} / \mathrm{N})$ ratio and variance analysis (ANOVA) of the cutting force and surface roughness are analyzed, and the response optimization method is used to suggest the optimal machining parameters.
\end{abstract}

Keywords: laser-assisted machining; Taguchi method; optimal machining conditions; machiningcharacteristic

\section{Introduction}

In recent years, due to their superior properties, carbon matrix ceramic composites have been increasingly utilized instead of monolithic ceramics and traditional manufacturing materials. Carbon matrix ceramic composites have low density, are lightweight, and have good high temperature strength. The demand for ceramic composite materials is growing in many fields such as, the aerospace and automobile industry, because of their high mechanical properties. However, the carbon matrix ceramic composites have high hardness, brittleness, are inhomogeneous and anisotropic in nature because its structure is composed of a brittle matrix and reinforcing fibers. The impact behaviors of the fibers, such as pullout and delamination, cause low surface quality after machining. The particles such as $\mathrm{SiC}$ and $\mathrm{Al} 2 \mathrm{O} 3$ cause tool wear during machining [1-5]. Therefore, many researchers have studied the advanced machining technologies to machine the composite material effectively. The thermally assisted machining (TAM) is a method which is an effective process of machining difficult-to-cut materials [6]. 
TAM uses heat sources such as laser, induction, and plasma to locally preheat the workpiece and soften it. In particular, as laser technology has improved, many researchers have studied laser-assisted machining (LAM), a type of TAM $[7,8]$. The LAM is an eco-friendly machining method that uses the high-density laser beam to soften workpieces and removes the material with cutting tools along the machining path. In LAM, the thermal conductivity and specific heat of ceramic matrix composite is increased as the temperature is increased. When the $\mathrm{C} / \mathrm{SiC}$ is preheated above $400{ }^{\circ} \mathrm{C}$ with a laser, the composite is oxidized. The material behavior is changed from brittle to ductile in the range of glass transition temperature $\left(1050-1250^{\circ} \mathrm{C}\right)$. When the oxidation rate is high, the coefficient of friction is decreased. When the coefficient of friction is decreased and material behavior is changed from brittle to ductile, material removal rate (MRR) and machinability are improved [9-13]. Figure 1 shows a schematic diagram of the LAM process.

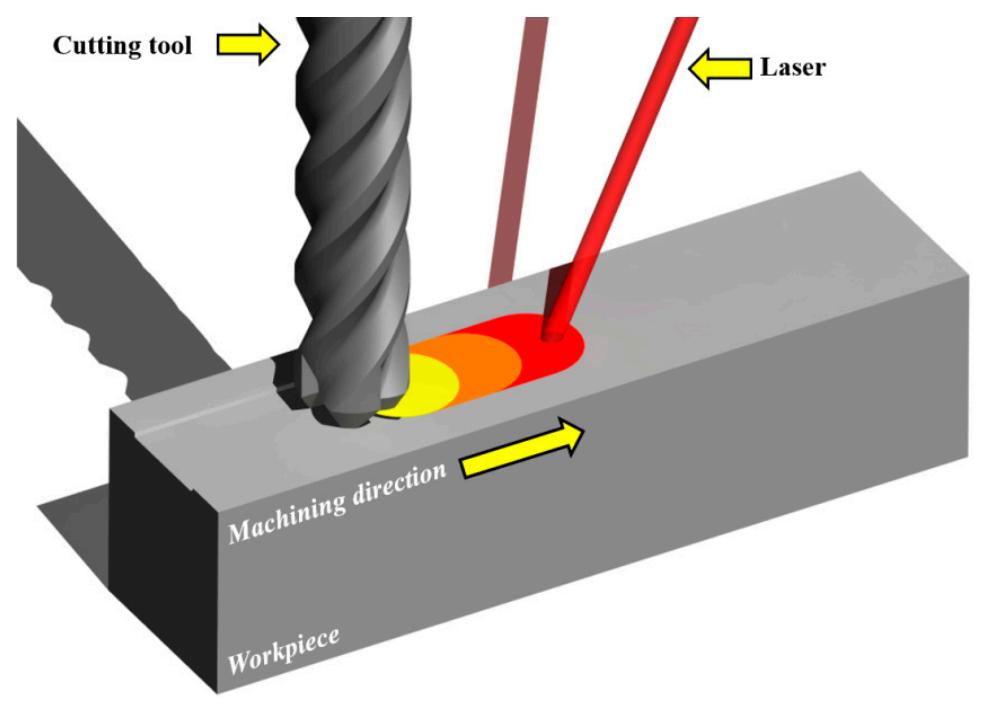

Figure 1. The schematic diagram of laser-assisted machining (LAM).

Many researchers are still investigating efficient methods for processing ceramic composites materials. Many researchers have been actively studying the carbon fiber reinforced silicon carbide $(\mathrm{C} / \mathrm{SiC})$ composites and also have considered the structural integrity and reliability of high temperature structures such as exhaust valves, automobile parts, aircraft parts, and nozzle necks by composites [1416]. Hui et al. investigated the changes in the tensile strength of $\mathrm{C} / \mathrm{SiC}$ composites according to the changes of specimen cross-section and heat treatment conditions [17]. It was found that the fracture work and residual strain increased as the cross-section of the specimen decreased. Tao et al. conducted static and dynamic compression tests in various temperature ranges and studied the resulting changes in compressive strength [18]. Research has found that compressive strength increases with increasing temperature, but decreases with decreasing temperature. Fattahi et al. focused on the analytical prediction of delamination during drilling composite laminates [19]. Chi et al. investigated the effects of cylindrical specimen size for IG-110 and NBG-18 on the compressive strength and Weibull modulus [20]. Chinmaya et al. compared experimental and simulated results for cutting forces for machining of $\mathrm{A} 359 / \mathrm{SiC} / 20 \mathrm{p}$ composites [21]. The effects of operating conditions under LAM were determined for the shear zone stress of silicon nitride by experimentation. Shuting Lei et al. and Damian Przestackid focused on improving the $\mathrm{Al} / \mathrm{SiC}$ composite machinability by LAM, and compared the results with those obtained when using the conventional turning process [22]. Except for the above-mentioned studies on the machining of composite materials using LAM, most studies have been performed with titanium and nickel alloys, and with various steels [23-26]. To date, there has been no research on using laser heat sources for preheating and machining of $\mathrm{C} / \mathrm{SiC}$ composite materials. In this study, the response optimization method is used to determine the optimal machining parameters 
in LAM of $\mathrm{C} / \mathrm{SiC}$ composite materials. This method is useful when evaluating the effect of multiple parameters on the response.

In this study, the experiments are performed to determine the optimal machining parameters and to analyze the thermal effect and machinability of the $\mathrm{C} / \mathrm{SiC}$ composite under various machining conditions in the LAM process. The effective depth of cut for LAM of C/SiC composite is obtained by finite element analysis according to preheating temperature. Then, LAM experiments are performed for flat shaped $\mathrm{C} / \mathrm{SiC}$. The influence of the machining parameters such as depth of cut, preheating temperature, feed rate, and spindle speed on cutting force, surface roughness, and tool wear is analyzed using the Taguchi method. The cutting force is measured by a dynamometer and the surface roughness is measured by the shape measuring device. For the determination of the optimal machining parameters, the response optimization method is performed. An efficient machining condition to increase machinability is proposed and discussed.

\section{Finite Element Analysis}

\subsection{Finite Element Analysis}

The finite element analysis method is performed to study the overlapping in the laser heat source according to the feed rate. The moving time of the heat source for the analysis was set to be in the range of $10-30 \mathrm{sec}$ by considering the feed rate $(\mathrm{f}=100-300 \mathrm{~mm} / \mathrm{min})$. The material properties for the analysis are listed in Table 1 . The main components of $\mathrm{C} / \mathrm{SiC}$ composite are reported in Table 2 . The preheating temperature was chosen by considering the tensile strength of $\mathrm{C} / \mathrm{SiC}$ composite material according to the temperature, as shown in Figure 2. The tensile strength of the $\mathrm{C} / \mathrm{SiC}$ composite decreases at the temperature ranges from the room temperature to $1300^{\circ} \mathrm{C}$ [27]. Additionally, $\mathrm{C} / \mathrm{SiC}$ composite material has its maximum elongation and minimum tensile strength at a temperature of about $1300^{\circ} \mathrm{C}$. The temperature range of the effective depth of the cut is $1100-1300^{\circ} \mathrm{C}$. To increase the accuracy of the analysis, the mesh elements are divided into squares of $1 \mathrm{~mm}$ and the preheated sections are localized at a mesh size of $0.5 \mathrm{~mm}$. The mesh consists of 66,267 nodes and 16,425 elements. Figure 3 shows the analysis model of the specimen and shows the shape of the generated mesh.

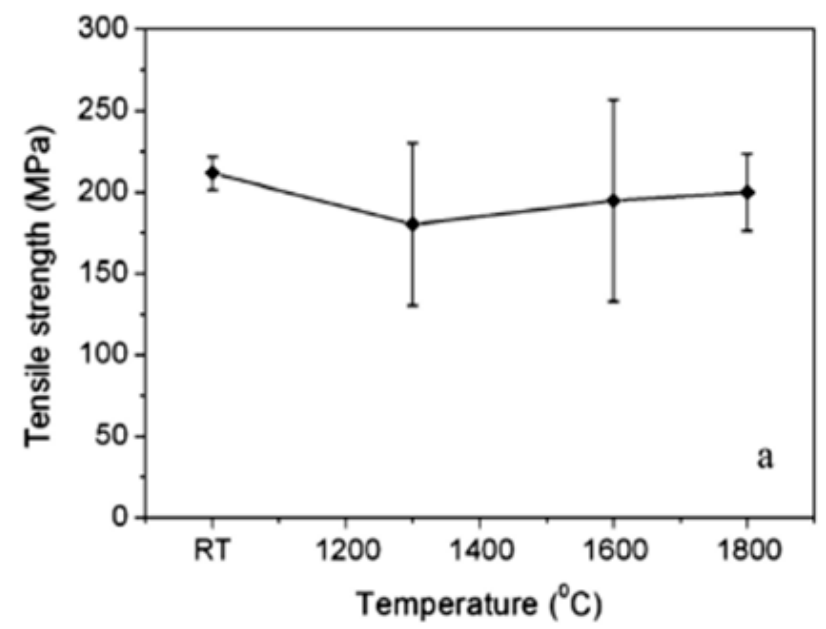

Figure 2. The tensile stress value according to temperature of $\mathrm{C} / \mathrm{SiC}$ composite.

Table 1. Mechanical properties of $\mathrm{C} / \mathrm{SiC}$ composite.

\begin{tabular}{ccccc}
\hline $\begin{array}{c}\text { Density } \\
\left(\mathrm{g} / \mathbf{c m}^{\mathbf{3}}\right)\end{array}$ & $\begin{array}{c}\text { Young Modulus } \\
(\mathrm{GPa})\end{array}$ & $\begin{array}{c}\text { Thermal Conductivity } \\
(\mathbf{W} / \mathbf{m m}-\mathbf{K})\end{array}$ & $\begin{array}{c}\text { Specific Heating } \\
\mathbf{( J / k g - K )}\end{array}$ & $\begin{array}{c}\text { Flexural Strength } \\
\mathbf{( M P a})\end{array}$ \\
\hline 2.1 & 35 & 40 & 1200 & 67 \\
\hline
\end{tabular}




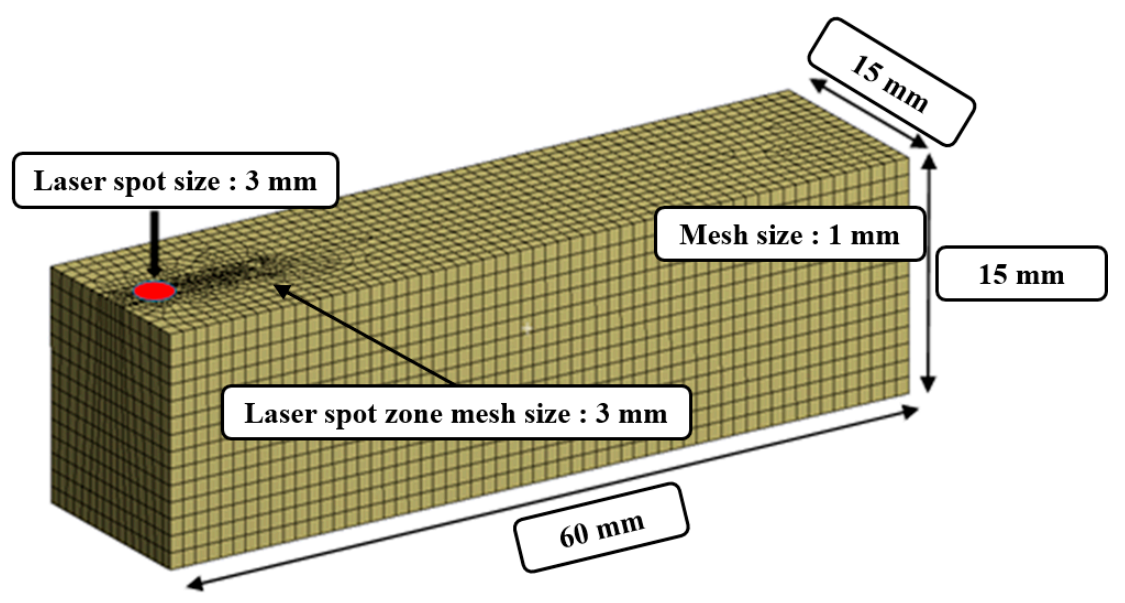

Figure 3. The finite element analysis model.

Table 2. The main components of $\mathrm{C} / \mathrm{SiC}$ composite.

\begin{tabular}{|c|c|c|c|}
\hline \multicolumn{3}{|c|}{ The Composition by X-ray Analysis (\%) } & \multirow{2}{*}{$\begin{array}{c}\text { Open Porosity (qv) } \\
(\%)\end{array}$} \\
\hline C & $\mathrm{SiC}$ & Residual Si & \\
\hline 50.47 & 44.81 & 4.72 & 5.40 \\
\hline
\end{tabular}

\subsection{Result of Analyis}

The finite element analysis result, the temperature distribution for the section view of the workpiece was used to determine the effective depth of cut according to preheating temperature. The effective depth of the cut is selected to be the depth at the temperature range of $1100-1300{ }^{\circ} \mathrm{C}$ where the strength of the material decreases. The analysis result, the effective depth of the cut was determined to be in the region of $0.2-0.4 \mathrm{~mm}$ at a preheating temperature range of $1100-1300{ }^{\circ} \mathrm{C}$. Figure 4 shows the finite element analysis results, and effective depth of cut according to the preheating temperature.
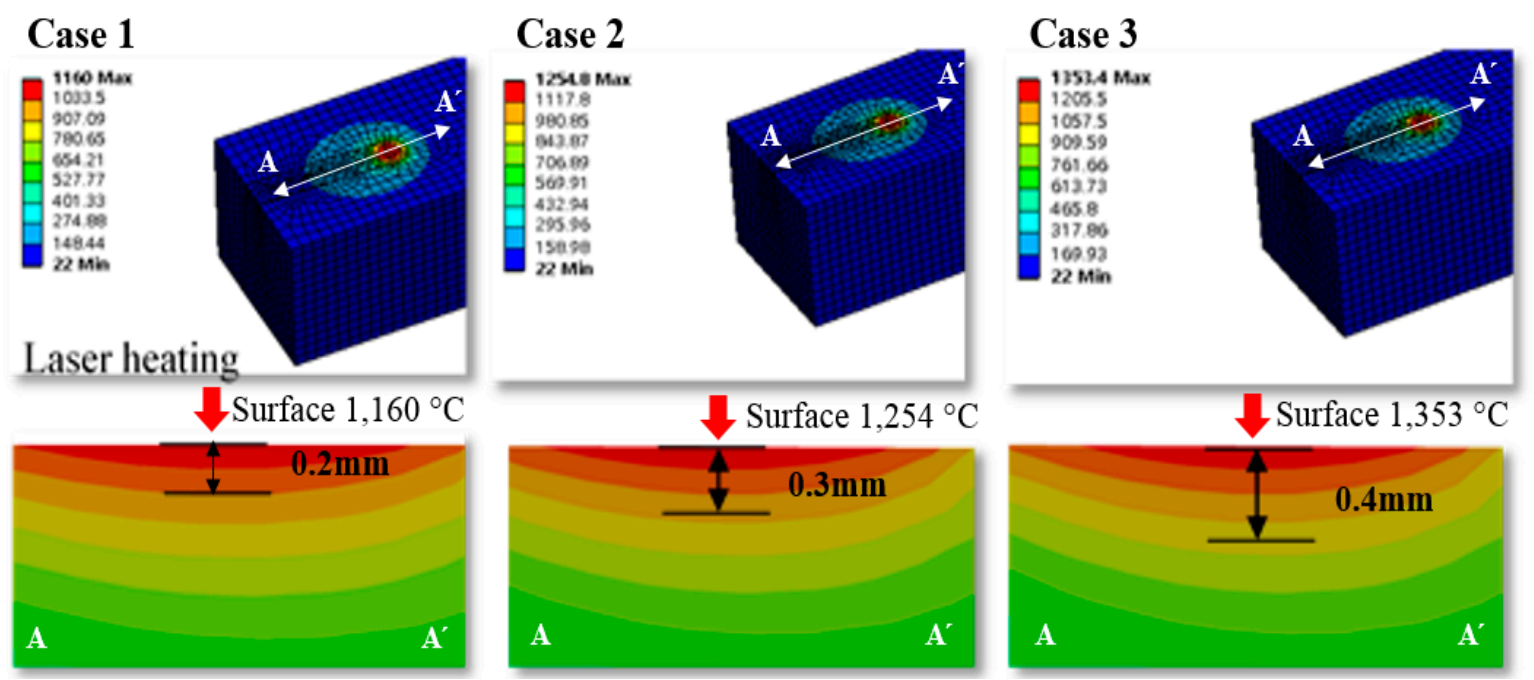

Figure 4. The finite element analysis result and the effective depth of the cut according to the preheating temperature. 


\section{Laser-Assisted Machining}

\subsection{Procedure}

The design of the experiment was performed to determine optimal machining conditions for the LAM of C/SiC composites. The object functions are selected as cutting force and surface roughness. The parameters such as depth of cut, preheating temperature, spindle speed, and feed rate are selected. The depth of cut is determined by the results of finite element analysis. Figure 5 shows the flow chart of the design of experiments for the LAM of C/SiC composite.

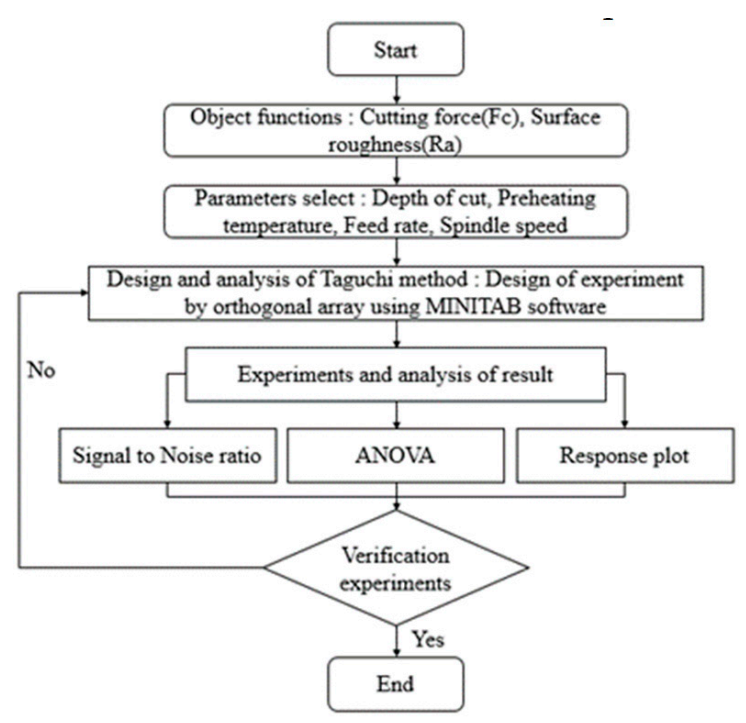

Figure 5. Flow chart of the design of experiments for the laser-assisted machining (LAM) of the $\mathrm{C} / \mathrm{SiC}$ composite.

\subsection{Machining Conditions}

The LAM process was performed on the 5-axis machining center (Hyundai WIA., Type Hi-V560M) with laser module. The laser module is a high-power diode laser (HPDL) with a wavelength range of 940-980 nm (Laser line Inc., Type LDM 1000-100). To measure the preheating temperature, a pyrometer (Dr. Mergemthaler $\mathrm{GmbH} \& \mathrm{Co}$. KG, LPC03) with a range of $400-3000{ }^{\circ} \mathrm{C}$ was used. The dynamometer (Kistler Inc., 9257B) attached to the indexing table was used to measure the cutting forces. A dynamometer measures the three orthogonal components of a force using the quartz three-component measurement. The measurement range is $-5 \mathrm{kN}$ to $5 \mathrm{kN}$, and the rigidity is $1 \mathrm{kN} / \mu \mathrm{m}$ to $2 \mathrm{kN} / \mu \mathrm{m}$. The surface roughness measurement device (Kosaka Inc., SE-3500K) and field emission scanning electron microscope (ZEISS Inc., MERLIN) were used to measure the surface roughness. The surface roughness measurement device was a probe type with a resolution of 32,000 points/16 bite. The surface roughness measurement device used the Gaussian profile filter to separate the long and short wave of a surface profile, and a cut-off value of $0.25 \mathrm{~mm}$ was used in this study. Figure 6 shows the experimental set-up and Table 3 shows machining conditions.

Table 3. The machining conditions.

\begin{tabular}{cc}
\hline Material & C/SiC Composite \\
\hline Material size $(\mathrm{T} \times \mathrm{W} \times \mathrm{L}, \mathrm{mm})$ & $15 \times 15 \times 60$ \\
\hline Machining method & Slot milling \\
\hline Cutting tool & D8 CBN flat end-mill, 2F, 70L \\
\hline
\end{tabular}



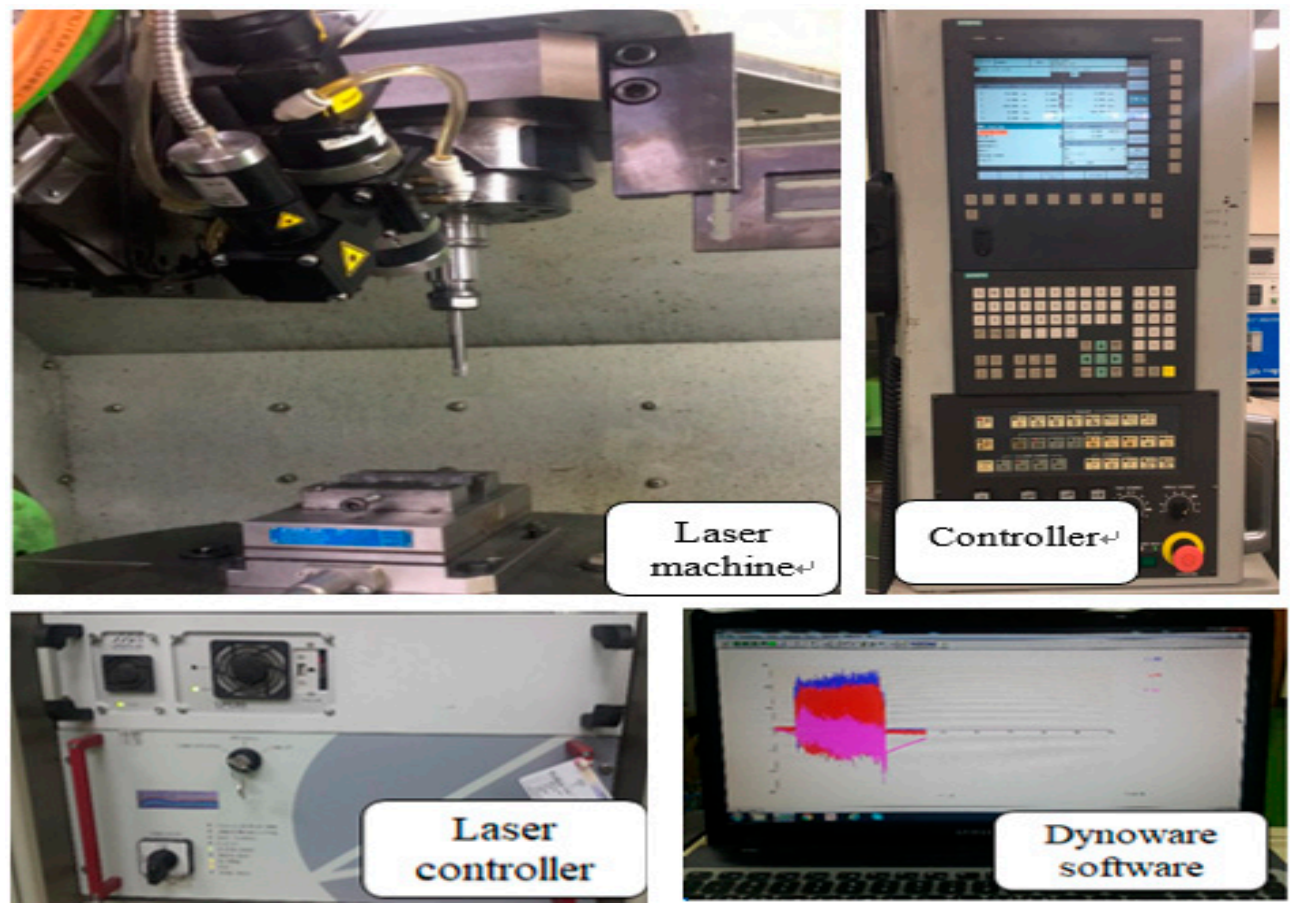

Figure 6. The experimental setup.

\subsection{Experimental Design}

In LAM, machining characteristics of $\mathrm{C} / \mathrm{SiC}$ composite are affected by various factors. To analyze the influence of the factors on the machining characteristics, the experiments should be performed after considering all the combinations of factors. However, in this case, the number of experiments increases and it is costly and time-consuming. Therefore, the design of experiment should be performed to reduce the cost and time. The experimental design proposed by the Taguchi method uses orthogonal arrays to organize the parameters that affect the process and varies the levels of those parameters. The Taguchi approach values the importance of the logic of the parameters and has a strong effect compared to actual experiments [28-32]. The Taguchi method used signal to noise $(\mathrm{S} / \mathrm{N})$ as a quality characteristic. The $\mathrm{S} / \mathrm{N}$ ratio characteristics can be divided into three types: nominal-is-best characteristics, larger-the-better characteristics, and smaller-the-better characteristics. In this study, the smaller-the-better characteristics were used. The smaller-the-better characteristics are shown in Equation (1).

$$
\mathrm{SN}=-10 \log \left[\frac{1}{n} \sum_{i=1}^{n} y_{i}^{2}\right]
$$

where, $y_{i}$ is the average of the observed data, $n$ is the number of observations, and $y$ represents the observed data or each type of characteristic; with the above $\mathrm{S} / \mathrm{N}$ ratio transformation, the smaller the $\mathrm{S} / \mathrm{N}$ ratio is, the better are the results for cutting force and surface roughness.

The cutting parameters for the LAM are the depth of cut (A), preheating temperature (B), feed rate (C), and spindle speed (D). The depth of the cut range $(0.2-0.4 \mathrm{~mm})$ was selected based on the finite element analysis result. The preheating temperature range $\left(1100-1300^{\circ} \mathrm{C}\right)$ was selected based on the tensile strength of $\mathrm{C} / \mathrm{SiC}$ composite material according to the temperature. The feed rate range (100-300 $\mathrm{mm} / \mathrm{min}$ ) and the spindle speed range (2000-8000 rpm) were selected after considering previous studies. The conventional machining (CM) was performed to verify the efficiency of the LAM. Table 4 shows the factors and levels used in the experiments and Table 5 shows the experimental layout using an $\mathrm{L}_{9}$ orthogonal array [33,34]. 
Table 4. The factors and levels used in the experiments.

\begin{tabular}{ccccc}
\hline Symbol & Factor & Level 1 & Level 2 & Level 3 \\
\hline A & Depth of cut $(\mathrm{mm})$ & 0.2 & 0.3 & 0.4 \\
B & Preheating temperature $\left({ }^{\circ} \mathrm{C}\right)$ & 1100 & 1200 & 1300 \\
C & Feed rate $(\mathrm{mm} / \mathrm{min})$ & 100 & 200 & 300 \\
$\mathrm{D}$ & Spindle speed $(\mathrm{rpm})$ & 2000 & 5000 & 8000 \\
\hline
\end{tabular}

Table 5. The experimental layout using an $\mathrm{L}_{9}$ orthogonal array.

\begin{tabular}{ccccc}
\hline Experiment No. & $\begin{array}{c}\text { Depth of Cut } \\
(\mathbf{m m})\end{array}$ & $\begin{array}{c}\text { Preheating } \\
\text { Temperature }\left({ }^{\circ} \mathbf{C}\right)\end{array}$ & $\begin{array}{c}\text { Feed Rate } \\
(\mathbf{m m} / \mathbf{m i n})\end{array}$ & $\begin{array}{c}\text { Spindle Speed } \\
(\mathbf{r p m})\end{array}$ \\
\hline CM & 0.2 & 1100 & 100 & 2000 \\
1 & 0.2 & 1100 & 100 & 2000 \\
2 & 0.2 & 1200 & 200 & 5000 \\
3 & 0.2 & 1300 & 300 & 8000 \\
4 & 0.3 & 1100 & 200 & 8000 \\
5 & 0.3 & 1200 & 300 & 2000 \\
6 & 0.3 & 1300 & 100 & 5000 \\
7 & 0.4 & 1100 & 300 & 5000 \\
8 & 0.4 & 1200 & 100 & 8000 \\
9 & 0.4 & 1300 & 200 & 2000 \\
\hline
\end{tabular}

\subsection{Experimental Results on LAM}

The cutting forces were measured using a tool dynamometer during the machining of $\mathrm{C} / \mathrm{SiC}$ composite material. The surface integrity was analyzed by the surface roughness measurement device and a field emission scanning electron microscope (FE-SEM). All experiments were repeated three times. The cutting force was calculated by the average value of each experiment and the surface roughness was used as the lowest value of each experiment. Figure 7 shows the microphotographs of the machined surfaces of C/SiC composite material in all experiments. Table 6 shows the measured cutting force and surface roughness according to the four factors of the machining conditions. In LAM, the cutting force was decreased by about $40.7 \%$ and the surface roughness was decreased by about $33.8 \%$, compare to the $\mathrm{CM}$. The lowest cutting force value at $A_{2} B_{3} C_{1} D_{2}$ was $42.25 \mathrm{~N}$, and the surface roughness of the $S / N$ ratio had the highest value of $-32.5165 \mathrm{~dB}$. Figure 8a shows that the optimal levels were found to be $A_{2}$ (depth of cut: $0.3 \mathrm{~mm}$ ), $B_{3}$ (preheating temperature: $1300{ }^{\circ} \mathrm{C}$ ), $C_{1}$ (feed rate: $100 \mathrm{~mm} / \mathrm{min}$ ), and $\mathrm{D}_{2}$ (spindle speed: $5000 \mathrm{rpm}$ ). The lowest surface roughness value at $\mathrm{A}_{2} \mathrm{~B}_{3} \mathrm{C}_{1} \mathrm{D}_{2}$ was $1.26 \mu \mathrm{m}$, and the surface roughness of the $\mathrm{S} / \mathrm{N}$ ratio had the highest value of $-2.0074 \mathrm{~dB}$. Figure $8 \mathrm{~b}$ shows the optimal levels were found to be $A_{2}$ (depth of cut: $0.3 \mathrm{~mm}$ ), $B_{3}$ (preheating temperature: $1300{ }^{\circ} \mathrm{C}$ ), $C_{1}$ (feed rate: $100 \mathrm{~mm} / \mathrm{min}$ ), and $\mathrm{D}_{2}$ (spindle speed: 5000 $\mathrm{rpm}$ ). Tables 7 and 8 shows the response table mean $\mathrm{S} / \mathrm{N}$ ratio for the cutting force and surface roughness according to the machining conditions.

Table 6. The experimental data value of cutting force and surface roughness.

\begin{tabular}{ccccccc}
\hline No. & $\begin{array}{c}\text { Depth of } \\
\text { Cut }(\mathbf{m m})\end{array}$ & $\begin{array}{c}\text { Preheating } \\
\text { Temperature }\left({ }^{\circ} \mathbf{C}\right)\end{array}$ & $\begin{array}{c}\text { Feed Rate } \\
(\mathbf{m m} / \mathbf{m i n})\end{array}$ & $\begin{array}{c}\text { Spindle } \\
\text { Speed (rpm) }\end{array}$ & $\begin{array}{c}\text { Surface } \\
\text { Roughness }(\boldsymbol{\mu m})\end{array}$ & $\begin{array}{c}\text { Cutting } \\
\text { Force }(\mathbf{N})\end{array}$ \\
\hline $\mathrm{CM}$ & 0.2 & 1100 & 100 & 2000 & 5.95 & 105.90 \\
1 & 0.2 & 1100 & 100 & 2000 & 3.94 & 62.80 \\
2 & 0.2 & 1200 & 200 & 5000 & 3.20 & 87.77 \\
3 & 0.2 & 1300 & 300 & 8000 & 6.80 & 50.79 \\
4 & 0.3 & 1100 & 200 & 8000 & 2.54 & 55.60 \\
5 & 0.3 & 1200 & 300 & 2000 & 4.65 & 129.50 \\
6 & 0.3 & 1300 & 100 & 5000 & 1.26 & 42.25 \\
7 & 0.4 & 1100 & 300 & 5000 & 1.95 & 72.58 \\
8 & 0.4 & 1200 & 100 & 8000 & 1.85 & 159.36 \\
9 & 0.4 & 1300 & 200 & 2000 & 4.30 & 90.63 \\
\hline
\end{tabular}


No. $1: 3.94 \mu \mathrm{m}$

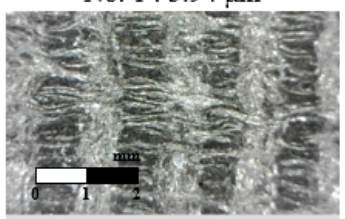

$\mathrm{CM}: 5.95 \mu \mathrm{m}$
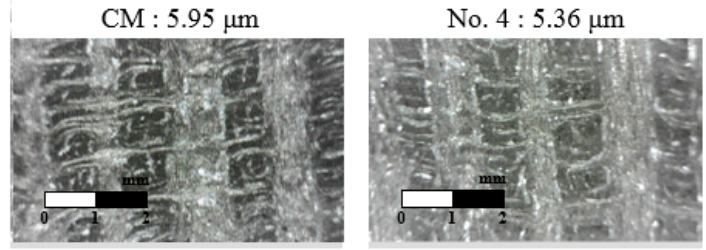

No. $7: 1.95 \mu \mathrm{m}$

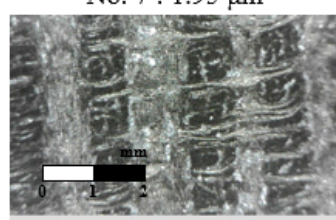

No. $2: 3.20 \mu \mathrm{m}$

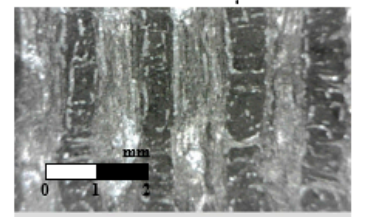

No. $5: 4.65 \mu \mathrm{m}$

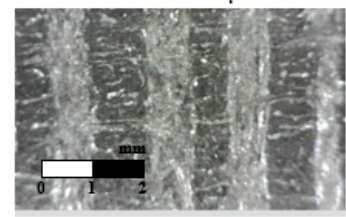

No. $8: 1.85 \mu \mathrm{m}$

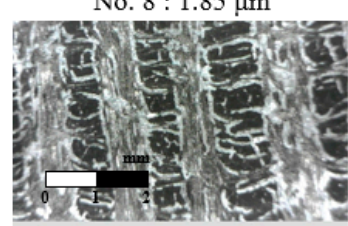

No. $3: 4.30 \mu \mathrm{m}$

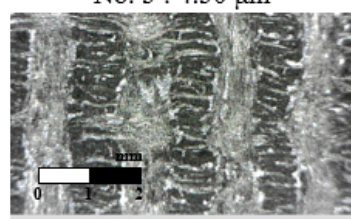

No. $6: 5.80 \mu \mathrm{m}$

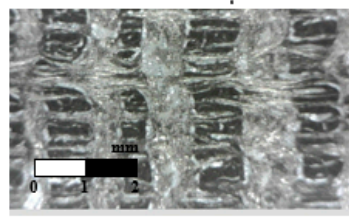

No. $9: 1.26 \mu \mathrm{m}$

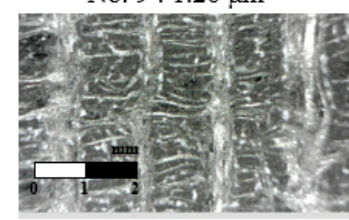

Figure 7. The microphotographs of machined surfaces of $\mathrm{C} / \mathrm{SiC}$ composite material in LAM.

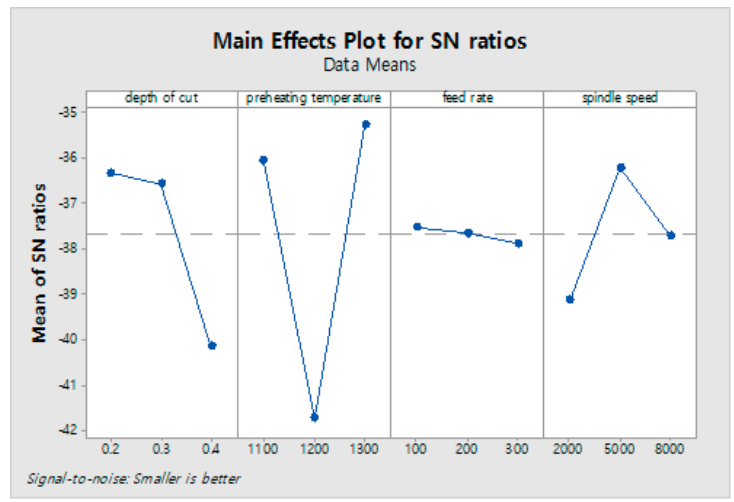

(a) Cutting force

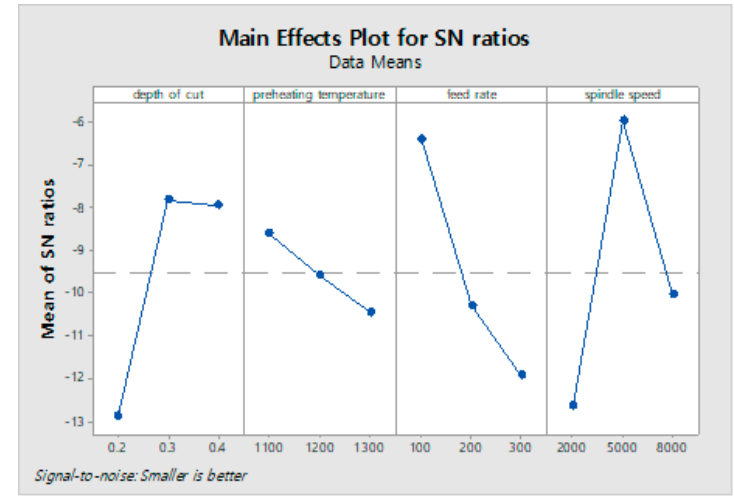

(b) Surface roughness

Figure 8. The main effect plot of $\mathrm{C} / \mathrm{SiC}$ composite on the cutting force and the surface roughness. (a) Cutting force; (b) Surface roughness.

Table 7. The response table mean signal to noise $(\mathrm{S} / \mathrm{N})$ ratio for the cutting force according to the machining conditions.

\begin{tabular}{ccccc}
\hline Level & Depth of Cut (A) & $\begin{array}{c}\text { Preheating } \\
\text { Temperature (B) }\end{array}$ & Feed Rate (C) & Spindle Speed (D) \\
\hline 1 & -36.31 & -36.03 & -37.51 & -39.12 \\
2 & -36.55 & -41.72 & -37.64 & -36.20 \\
3 & -40.14 & -35.26 & -37.86 & -37.69 \\
Delta & 3.82 & 6.46 & 0.35 & 2.92 \\
Rank & 2 & 1 & 4 & 3 \\
\hline
\end{tabular}


Table 8. The response table mean $\mathrm{S} / \mathrm{N}$ ratio for the surface roughness according to the machining conditions.

\begin{tabular}{ccccc}
\hline Level & Depth of Cut (A) & $\begin{array}{c}\text { Preheating } \\
\text { Temperature (B) }\end{array}$ & Feed Rate (C) & Spindle Speed (D) \\
\hline 1 & -12.888 & -8.602 & -6.420 & -12.643 \\
2 & -7.818 & -9.598 & -10.290 & -5.970 \\
3 & -7.938 & -10.442 & -11.933 & -10.030 \\
Delta & 5.070 & 1.840 & 5.513 & 6.672 \\
Rank & 3 & 4 & 2 & 1 \\
\hline
\end{tabular}

\subsection{Variance Analysis}

Variance analysis (ANOVA) was applied to the $\mathrm{S} / \mathrm{N}$ ratios to determine the relations between machining parameters relating to surface roughness and cutting force. The calculated $\mathrm{S} / \mathrm{N}$ ratio for the four factors of the surface roughness and cutting force in the machining of $\mathrm{C} / \mathrm{SiC}$ composites are shown in Tables 9 and 10. In these results, the most significant influences on the cutting force value for each factor were the percentage contributions of the factors of preheating temperature, depth of cut, spindle speed, and feed rate; these percentages were $66.23 \%, 22.55 \%, 9.91 \%$, and $1.31 \%$, respectively. Also, the factors that contributed to the surface roughness were determined; the most important factor was $31.24 \%$ for the spindle speed, the second factor was $29.69 \%$ for the depth of cut, the third factor was $27.93 \%$ for the preheating temperature, and the fourth factor was $11.13 \%$ for the feed rate.

Table 9. The analysis results of variance for cutting force.

\begin{tabular}{ccccc}
\hline Factors & Degree of Freedom & Sum of Squares & Mean of Squares & Contribution (\%) \\
\hline Feed rate & 2 & 157.1 & 78.56 & $1.31 \%$ \\
Spindle speed & 2 & 1192.9 & 596.44 & $9.91 \%$ \\
Depth of cut & 2 & 2714.9 & 1357.46 & $22.55 \%$ \\
Preheating & 2 & 7972.5 & 3986.27 & $66.23 \%$ \\
temperature & 0 & $*$ & $*$ & $*$ \\
Error & 8 & 12037.5 & - & 100 \\
Total & & & \\
\hline
\end{tabular}

Table 10. The analysis results of variance for surface roughness.

\begin{tabular}{ccccc}
\hline Factors & Degree of Freedom & Sum of Squares & Mean of Squares & Contribution (\%) \\
\hline Feed rate & 2 & 6.728 & 3.364 & $27.93 \%$ \\
Spindle speed & 2 & 7.525 & 3.763 & $31.24 \%$ \\
Depth of cut & 2 & 7.152 & 3.576 & $29.69 \%$ \\
Preheating & 2 & 2.681 & 1.341 & $11.13 \%$ \\
temperature & 0 & $*$ & $*$ & $*$ \\
Error & 8 & 24.087 & - & 100 \\
Total & & & & \\
\hline
\end{tabular}

\section{Experimental Results and Discussion}

\subsection{Signal to Noise (S/N) Ratio of Analysis}

$\mathrm{S} / \mathrm{N}$ ratio is a very important measurement in the Taguchi method for experimental data analysis. According to the Taguchi approach, optimal machining condition values should lead to a maximum $\mathrm{S} / \mathrm{N}$ ratio. Parameter values are important factors for evaluating the surface roughness and cutting force. Other characteristics contribute slightly to the cutting force and surface roughness evaluation. Results of machining experiments have been studied using the $\mathrm{S} / \mathrm{N}$ ratio. Based on the predictions and response results of the ANOVA analyses, optimal machining parameters for cutting force and surface roughness were obtained and verified. The correlation test between the cutting force and surface 
roughness was performed by analyzing the correlation coefficient (r). The result of the correlation test, the correlation between the two parameters was a positive correlation and $\mathrm{r}$ was 0.223 . The correlation coefficient ranged from -1 to 1 and describes the parametric value of linear relationship.

\subsection{Response Optimization}

The objective of this experiment is to optimize the machining parameters and to develop better (i.e., low value) surface roughness and cutting force values; the "smaller the better" characteristic was used. The optimal machining conditions, which were the depth of cut of $0.3 \mathrm{~mm}$, preheating temperature of $1100{ }^{\circ} \mathrm{C}$, the feed rate of $200 \mathrm{~mm} / \mathrm{min}$, and a spindle speed of $5000 \mathrm{rpm}$ were obtained for the best cutting force and surface roughness values. The desirability is confirmed at 1 . According to the Taguchi design results obtained for the cutting force and surface roughness, the response optimization results are given in Tables 11 and 12.

Table 11. The response optimization.

\begin{tabular}{cccccc}
\hline Parameter & Goal & Target & Upper & Weight & Importance \\
\hline $\begin{array}{c}\text { Cutting force } \\
\text { Surface } \\
\text { roughness }\end{array}$ & Minimum & 42.25 & 159.36 & 1 & 1 \\
\hline
\end{tabular}

Table 12. Response optimization results.

\begin{tabular}{cc}
\hline Depth of Cut $(\mathrm{mm})$ & 0.3 \\
\hline Preheat temperature $\left({ }^{\circ} \mathrm{C}\right)$ & 1100 \\
\hline Feed rate $(\mathrm{mm} / \mathrm{min})$ & 200 \\
\hline Spindle speed $(\mathrm{rpm})$ & 5000 \\
\hline Curface roughness optimization plot $(\mu \mathrm{m})$ & 34.55 \\
\hline Desirability & 0.946667 \\
\hline
\end{tabular}

\subsection{Prediction Equations and Confirmation Experiments of the Optimal Condition}

Confirmation experiments were conducted to calculate the suitability of the analysis results. The prediction equations for the cutting force and the surface roughness are shown in Equations (2) and (3).

$$
\begin{gathered}
F c=83.48+10.83(\mathrm{~S} 2000)-15.94(\mathrm{~S} 5000)+5.108(\mathrm{~S} 8000)+4.661(\mathrm{~F} 100) \\
-5.476(\mathrm{~F} 200)+0.8144(\mathrm{~F} 300)-19.82(\mathrm{P} 1100)+42.07(\mathrm{P} 1200)-22.25(\mathrm{P} 1300) \\
-16.36(\mathrm{D} 0.2)-7.692(\mathrm{D} 0.3)+24.05(0.4) \\
\\
R a=3.388+0.9089(\mathrm{~S} 2000)-1.251(\mathrm{~S} 5000)+0.3422(\mathrm{~S} 8000)-1.038(\mathrm{~F} 100) \\
-0.04111(\mathrm{~F} 200)+1.079(\mathrm{~F} 300)-0.5778(\mathrm{P} 1100)-0.1544(\mathrm{P} 1200)+0.7322(\mathrm{P} 1300) \\
+1.259(\mathrm{D} 0.2)-0.5711(\mathrm{D} 0.3)-0.6878(\mathrm{D} 0.4)
\end{gathered}
$$

where, $F c$ represents the cutting force, and $R a$ represents the surface roughness. Table 13 shows the machining conditions of the confirmation experiment. The three experiments were conducted by randomly adding four machining conditions, including optimal machining conditions (Exp. No. 1) and the main effect of surface roughness (Exp. No. 2), are deducted in Table 13. All experiments were repeated three times. Figure 9 shows the comparison of the results of the prediction equation and the confirmation experiments for the cutting force. As a result of the comparison, the maximum error rate was confirmed to be approximately $7.55 \%$. Figure 10 shows the comparison of the results of the prediction equation and the confirmation experiments for the surface roughness. As a result of 
the comparison, the maximum error rate was confirmed to be approximately $8.76 \%$. Confirmation experiments were conducted to verify the optimal machining parameters.

Table 13. The machining conditions for confirmation experiments.

\begin{tabular}{ccccc}
\hline Exp. No. & $\begin{array}{c}\text { Depth of Cut } \\
(\mathbf{m m})\end{array}$ & $\begin{array}{c}\text { Preheating } \\
\text { Temperature }\left({ }^{\circ} \mathbf{C}\right)\end{array}$ & $\begin{array}{c}\text { Feed Rate } \\
(\mathbf{m m} / \mathbf{m i n})\end{array}$ & $\begin{array}{c}\text { Spindle Speed } \\
(\mathbf{r p m})\end{array}$ \\
\hline 1 & 0.2 & 1200 & 100 & 2000 \\
2 & 0.3 & 1200 & 200 & 5000 \\
3 & 0.4 & 1200 & 300 & 2000 \\
\hline
\end{tabular}

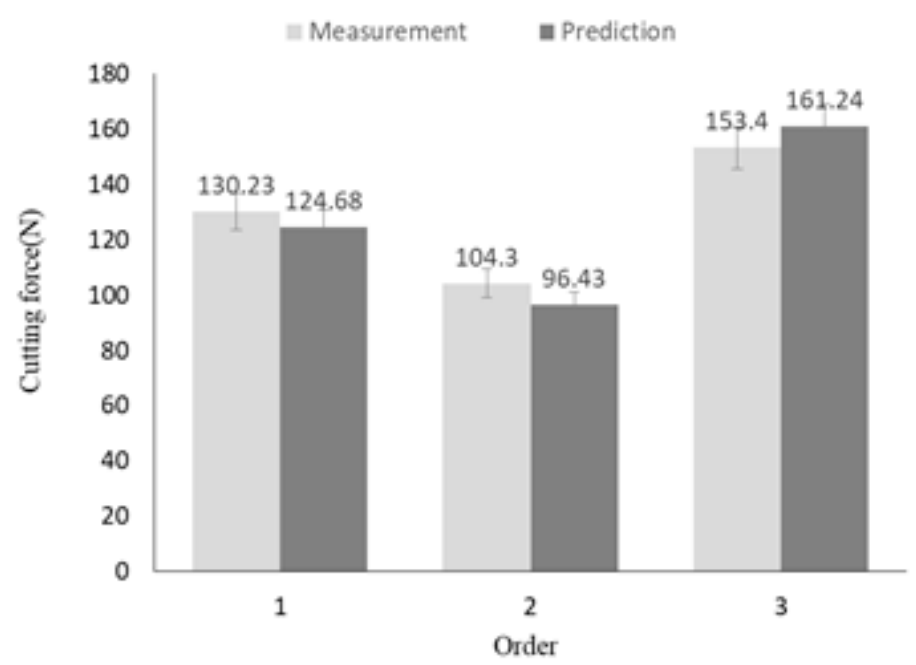

Figure 9. The comparison of the cutting force between the prediction equation results and the confirmation experiment results.

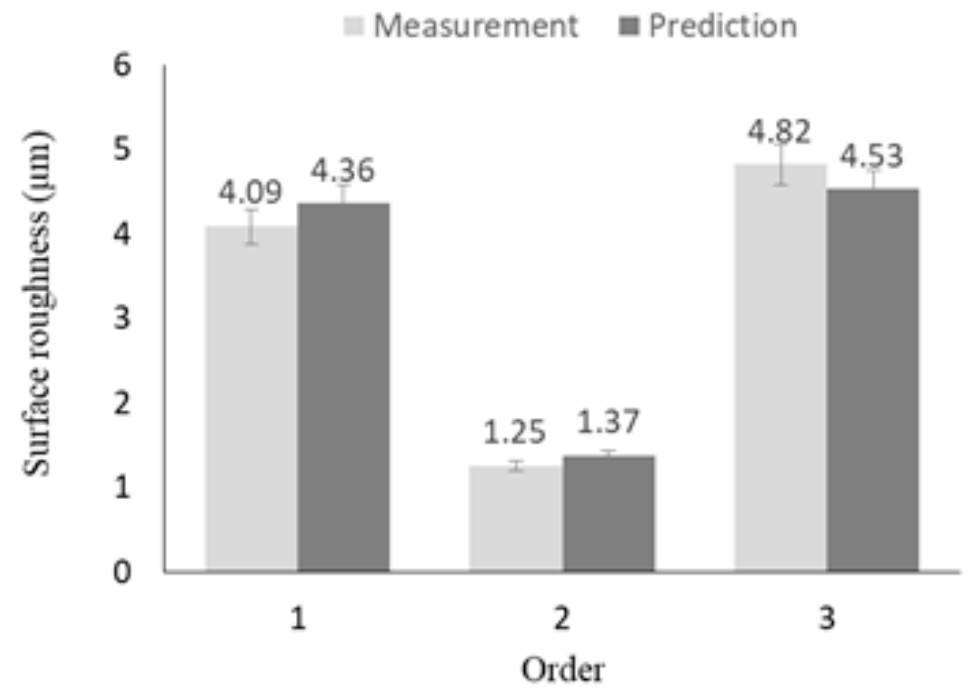

Figure 10. The comparison of the surface roughness between the prediction equation results and the confirmation experiment results.

\section{Conclusions}

In this study, LAM was carried out on the C/SiC composite material. The effective depth of cut was selected using the finite element analysis. The optimal machining conditions were obtained using the Taguchi method, which uses cutting force and surface roughness as objective function. The conclusions obtained from this study are as follows. 
(1). The finite element analysis was performed to determine the preheating temperature and the depth of cut depending on the tensile strength of the $\mathrm{C} / \mathrm{SiC}$ composite material. When the preheating temperature is in the tensile strength decreasing range $\left(1100-1300^{\circ} \mathrm{C}\right)$, the effective depth of cut is determined to be in the range of $0.2-0.4 \mathrm{~mm}$.

(2). According to the Taguchi standard design concept in this experiment, at three levels with four factors of each one, nine experiments must be performed, and fractional design was selected in a standard L9 orthogonal array. The maximum value was found using the $\mathrm{S} / \mathrm{N}$ ratio equation of "the smaller-the better"; the maximum $\mathrm{S} / \mathrm{N}$ ratio yielded the optimal machining parameters.

(3). In same case of the machining conditions, the cutting force was decreased by about $40.7 \%$ compared to $\mathrm{CM}$ in LAM of the $\mathrm{C} / \mathrm{SiC}$ composite material, and the surface roughness was decreased by about $33.8 \%$ compared to CM in LAM of the C/SiC composite material.

(4). Variance analysis (ANOVA) was applied to the $\mathrm{S} / \mathrm{N}$ ratio to discover the interactions between the parameters relating to surface roughness $(\mathrm{Ra})$ and cutting force $(\mathrm{Fc})$. Based on the ANOVA results, the main contributing factor for the cutting force was $66.23 \%$ preheating temperature. The main contributing factor for the surface roughness was $31.24 \%$ spindle speed.

(5). The verification experiment was performed to construct the predictive equation and to ensure the reliability of the predictive equation. The verification experiment confirmed that the maximum error was $7.55 \%$ between the prediction equation for cutting force and measurement experiment value. The maximum error was $8.76 \%$ between the prediction equation for surface roughness and measurement experiment value. The prediction equation demonstrated the reliability of low error.

The results of response optimization, the optimal machining conditions for LAM of the C/SiC composite material were obtained as spindle speed $(5000 \mathrm{rpm})$, feed rate $(200 \mathrm{~mm} / \mathrm{min})$, preheating temperature $\left(1100^{\circ} \mathrm{C}\right)$, and DOC $(0.3 \mathrm{~mm})$. When the experiment was performed by optimal machining conditions, the cutting force was measured to be $34.55 \mathrm{~N}$ and surface roughness was measured to be $0.95 \mu \mathrm{m}$.

Author Contributions: Conceptualization, K.E.; Data curation, H.J.; Formal analysis, H.J.; Funding acquisition, C.L.; Supervision, C.L.; Writing—original draft, K.E.; Writing—review \& editing, H.J.

Funding: This work was supported by the National Research Foundation of Korea (NRF) grant funded by the Korea government (MSIT) (No. 2019R1A2B5B03070206).

Conflicts of Interest: The authors declare no conflict of interest.

\section{References}

1. M'Saoubi, R.; Axinte, D.; Soo, S.L.; Nobel, C.; Attia, H.; Kappmeyer, G.; Engin, S.; Sim, W.M. High performance cutting of advanced aerospace alloys and composite materials. CIRP Ann. 2015, 64, 557-580. [CrossRef]

2. Mei, H.; Li, H.; Bai, Q.; Zhang, Q.; Cheng, L. Increasing the strength and toughness of a carbon fiber/silicon carbide composite by heat treatment. Carbon 2013, 54, 42-47. [CrossRef]

3. Appiah, K.A.; Wang, Z.L.; Lackey, W.J. Characterization of interfaces in C fiber-reinforced laminated C-SiC matrix composites. Carbon 2000, 38, 831-838. [CrossRef]

4. Mei, H.; Cheng, L.; Zhang, L.; Xu, Y. Modeling the effects of thermal and mechanical load cycling on a C/SiC composite in oxygen/argon mixtures. Carbon 2007, 45, 2195-2204. [CrossRef]

5. Shirvanimoghaddam, K.; Hamim, S.U.; Karbalaei, A.M.; Fakhrhoseini, S.M.; Khayyam, H.; Pakseresht, A.H.; Ghasali, E.; Zabet, M.; Munir, K.S.; Jia, S.; et al. Carbon fiber reinforced metal matrix composites: Fabrication processes and properties. Composites Part A 2017, 92, 70-96. [CrossRef]

6. López de Lacalle, L.N.; Sa'nchez, J.A.; Lamikiz, A.; Celaya, A. Plasma Assisted Milling of Heat-Resistant Superalloys. J. Manu. Sci. Eng. 2004, 126, 274-285. [CrossRef]

7. Chen, S.H.; Tsai, K.T. The study of plasma-assisted machining to Inconel-718. Adv. Mech. Eng. 2017, 9, 1-7. [CrossRef] 
8. Lo'pez de Lacalle, L.N.; Lamikiz, A.; Celaya, A. Simulation of Plasma Assisted Milling of Heat Resistant Alloys. Int. J. Simul. Modll. 2002, 1, 5-15.

9. Jeon, Y.; Lee, C.M. Current research trend on laser assisted machining. Int. J. Precis. Eng. Manuf. 2012, 13, 311-317. [CrossRef]

10. Kim, T.W.; Lee, C.M. Determination of the machining parameters of nickel-based alloys by High-Power diode laser. Int. J. Precis. Eng. Manuf. 2015, 16, 309-314. [CrossRef]

11. Sun, S.; Brandt, M.; Dargusch, M.S. Thermally enhanced machining of hard-to-machine materialsA review. Int. J. Mach. Tools Manuf. 2010, 50, 663-680. [CrossRef]

12. Bermingham, M.J.; Palanisamy, S.; Dargusch, M.S. Understanding the tool wear mechanism during thermally assisted machining Ti-6Al-4V. Int. J. Mach. Tools Manuf. 2012, 62, 76-87. [CrossRef]

13. Woo, W.S.; Lee, C.M. A study of the machining characteristics of AISI 1045 steel and Inconel 718 with a cylindrical shape in laser-assisted milling. Appl. Therm. Eng. 2015, 91, 33-42. [CrossRef]

14. Mei, H. Measurement and calculation of thermal residual stress in fiber reinforced ceramic matrix composites. Compos. Sci. Technol. 2008, 68, 15-16. [CrossRef]

15. Krenkel, W.; Berndt, F. C/C-SiC composites for space applications and advanced friction systems. Mater. Sci. Eng., A 2005, 412, 177-181. [CrossRef]

16. Leatherbarrow, A.; Wu, H. Mechanical behaviour of the constituents inside carbon-fibre/carbon-silicon carbide composites characterised by nano-indentation. J. Eur. Ceram. Soc. 2012, 32, 579-588. [CrossRef]

17. Mei, H.; Xiao, S.; Bai, Q.; Wang, H.; Li, H.; Cheng, L. The effect of specimen cross-sectional area on the strength and toughness of two-dimensional C/SiC composites. Ceram. Int. 2015, 41, 2963-2967. [CrossRef]

18. Suo, T.; Fan, X.; Hu, G.; Li, Y.; Tang, Z.; Xue, P. Compressive behavior of C/SiC composites over a wide range of strain rates and temperatures. Carbon 2013, 62, 481-492. [CrossRef]

19. Fattahi, Z.; Hegab, H.; Kishawy, H.A. Analytical Prediction of Delamination during Drilling Composite Laminates. Procedia Manuf. 2018, 26, 237-244. [CrossRef]

20. Chi, S.H. Specimen size effects on the compressive strength and Weibull modulus of nuclear graphite of different coke particle size: IG-110 and NBG-18. J. Nucl. Mater. 2013, 436, 185-190. [CrossRef]

21. Przestacki, D. Conventional and laser assisted machining of composite A359/20SiCp Procedia. Procedia CIRP 2014, 14, 229-233. [CrossRef]

22. Dandekar, C.R.; Shin, Y.C. Modeling of machining of composite materials: A review. Int. J. Mach. Tools Manuf. 2012, 57, 102-121. [CrossRef]

23. Brecher, C.; Emonts, M.; Rosen, C.J.; Hermani, J.P. Laser-assisted milling of advanced materials. Physics Procedia 2011, 12, 599-606. [CrossRef]

24. Dandekar, C.R.; Shin, Y.C.; Barnes, J. Machinability improvement of titanium alloy (Ti-6Al-4V) via LAM and hybrid machining. Int. J. Mach. Tools Manuf. 2010, 50, 174-182. [CrossRef]

25. Kang, D.W.; Lee, C.M. A study on the development of the laser-assisted milling process and a related constitutive equation for silicon nitride. CIRP Ann. 2014, 63, 109-112. [CrossRef]

26. Kim, D.H.; Lee, C.M. A study of cutting force and preheating-temperature prediction for laser-assisted milling of Inconel 718 and AISI 1045 steel. Int. J. Heat Mass Transfer 2014, 71, 264-274. [CrossRef]

27. Li, Z.; Xiao, P.; Xiong, X.; Huang, B.Y. Manufacture and properties of carbon fibre-reinforced C/SiC dual matrix composites. New Carbon Mater. 2010, 25, 225-231. [CrossRef]

28. Nalbant, M.; Gökkaya, H.; Sur, G. Application of Taguchi method in the optimization of cutting parameters for surface roughness in turning. Mater. Des. 2007, 28, 1379-1385. [CrossRef]

29. Somashekara, H.M.; Lakshmana, S.N. Optimizing Surface Roughness and MRR in turning operation using Taguchi's design of experiments approach. Int. J. Appl. Eng. Res. 2012, 7, 887-895.

30. Fratila, D.; Caizar, C. Application of Taguchi method to selection of optimal lubrication and cutting conditions in face milling of AlMg3. J. Cleaner Prod. 2011, 19, 640-645. [CrossRef]

31. Ghani, J.A.; Choudhury, I.A.; Hassan, H.H. Application of Taguchi method in the optimization of end milling parameters. J. Mater. Process. Technol. 2004, 145, 84-92. [CrossRef]

32. Kim, E.J.; Lee, C.M. A Study on the Optimal Machining Parameters of the Induction Assisted Milling with Inconel 718. Materials 2019, 12, 233. [CrossRef] [PubMed] 
33. Erdenechimeg, K. A study on the machining characteristics of composite material using Laser-assisted machining. M.S. dissertation, Changwon National University, Changwon, Gyeongsangnam-do, Korea. 2019. Available online: http://lib.changwon.ac.kr/search/DetailView.External.ax?edp1=edsker\&edp2=edsker. 000004669582\&sid=1\&widget_id=56\&linkID=1\&q= (accessed on 10 December 2018).

34. Research report of the National Research Foundation of Korea (NRF) (2019) A new conceptual 3-dimensional laser assisted machining system 2016R1A2A1A05005492. Available online: http://ernd.nrf.re.kr/ (accessed on June 2019).

(C) 2019 by the authors. Licensee MDPI, Basel, Switzerland. This article is an open access article distributed under the terms and conditions of the Creative Commons Attribution (CC BY) license (http://creativecommons.org/licenses/by/4.0/). 